\title{
QUALITY OF MEDICAL EDUCATION SYSTEM - INCREASING OR DECREASING
}

\author{
Deepak Arora1, Manmohan Krishan Mahajan², Manjeet Kaur ${ }^{3}$ \\ 1Professor, Department of Microbiology, GGMC, Faridkot. \\ 2 Professor, Department of Radiotherapy, ACI, Bathinda. \\ ${ }^{3}$ Associate Professor, Department of Pathology, ACI, Bathinda.
}

\section{ABSTRACT}

\section{BACKGROUND}

This study was aimed at determining the perception of Medical and Paramedical students towards the different teaching aids they are exposed to in teaching Medical Microbiology.

\section{MATERIALS AND METHODS}

A question-based survey was done involving second year MBBS undergraduate students, paramedical students who have passed second professional. A total of 50 students who had received lectures on different Microbiology topics, using Chalk and Talk, TOHP, PPT. Then, oral feedback was taken from the students to assess the preference of lecture delivery methods.

\section{RESULTS}

A comparison was carried out regarding the student's preference versus the performance in examination. In our study, it was found that although students preferred PPT > Blackboard > OHP as mode of teaching, but our results showed student's performance was better in terms of Blackboard > PPT > OHP.

\section{CONCLUSION}

We conclude that the dominant form of lecture delivery is still Blackboard, but with younger teachers opting more for multimedia method of teaching. We strongly recommend that MCI should take adequate steps to promote Blackboard teaching in medical colleges. MCI should not consider the competence of teacher based upon number of articles published but along with the number of lectures delivered based upon different teaching aids.

\section{KEYWORDS}

Blackboard, PPT, OHP, Microbiology, Lecture, Medical Colleges, MCI.

HOW TO CITE THIS ARTICLE: Arora D, Mahajan MK, Kaur M. Quality of medical education system - increasing or decreasing. J. Evolution Med. Dent. Sci. 2016;5(103):7547-7549, DOI: 10.14260/jemds/2016/1709

\section{BACKGROUND}

The medical education system in India is one of the largest in the world.[1] Western medicine was introduced in India by the arrival of the Portuguese in Goa and the British in other parts of India. The British established the Madras Medical School in 1835 and in 1840 the Portuguese started the Medicine and Pharmacy Licentiates, now known as Goa Medical College. University-affiliated medical education became the norm in the 1850s, after the opening of the first three Indian universities in Chennai, Mumbai and Kolkata.

The medical schools in India have seen rapid growth in the last 20 years, almost doubling in strength.[2] This growth has largely been in response to the growing population and its health needs, new health challenges have arisen due to increasing population, emergence of new diseases, as also due to increased lifespan and globalisation as well as excessive demand for Medical Degrees. This has created a marked shortage of medical teachers.

As lot of new private medical schools opening, there had been an acute shortage of faculty members; as the result the

Financial or Other, Competing Interest: None.

Submission 05-10-2016, Peer Review 13-12-2016,

Acceptance 19-12-2016, Published 26-12-2016.

Corresponding Author:

Dr. Deepak Arora,

Professor,

Department of Microbiology,

GGMC, Faridkot.

E-mail: drdeepakarora78@gmail.com

DOI: $10.14260 /$ jemds/2016/1709 existing faculty which are working in Medical Colleges bear a lot of burden as each of these colleges are running lots of Medical, Dental, Paramedical and Allied Programmes. This has led to development of different aids in education, which could help the faculty as same topics are to be covered for different courses at the same time.

Microbiology is an essential subject of second year MBBS course and medical students find the subject difficult and volatile. So, the present study was undertaken to evaluate the effectiveness of different teaching methods of India. To find out the better teaching aid that allows the students to understand the lifecycles of Parasite, Diagrams of Viruses, Bacteria and Flowcharts, etc.

So, this study was planned to fill the gap and to convey the opinion of students to their teachers. This article takes into account the student's perspective regarding teaching methodologies and a comparison of different methodologies in medical institutions and reforms to be taken for the elevation of medical education.

\section{MATERIALS AND METHODS}

This study comprises of total 50 students who recently passed 2nd MBBS course and paramedical courses in Microbiology. Irrespective of the topic, students were asked to grade the teaching aids and methods that were used to teach Microbiology in their full professional. In the medical institutions of Punjab, we observe the use of both conventional and non-conventional methods. The former encompasses blackboard and chalk with oral demonstrations and verbal dictations, while the latter consists of more modern teaching 
aids like Overhead Projectors (OHP), PowerPoint Presentations (PP), videos and animations. Medical students during their second year of Bachelor of Medicine and Bachelor of Surgery (MBBS) course, find Microbiology difficult and volatile. In this regard, we studied the feedback from students about the effectiveness of prevailing teaching aids and methods, so that the best teaching aid and method can be adopted to improve their academic performance.

A question-based survey was done involving second year MBBS undergraduate students, paramedical students who have passed second professional. A total of 50 students were who had received lectures on different Microbiology topics, using Chalk and Talk, TOHP, PPT. Then, oral feedback was taken from the students to assess the preference of lecture delivery methods.

\section{RESULTS}

As per the feedback by the students taking Microbiology lectures delivered by 3 methods, the results of the study showed that as per the subjective assessment of preference and performance of the students lectures concern, $71 \%$ preferred PowerPoint presentations (PPT) followed by Blackboard (20\%) and (9\%) preferred OHP, but while comparing the performance (67\%) of the student's performance was better in blackboard followed by PowerPoint presentations (PPT) 23\% and then OHP (10\%).

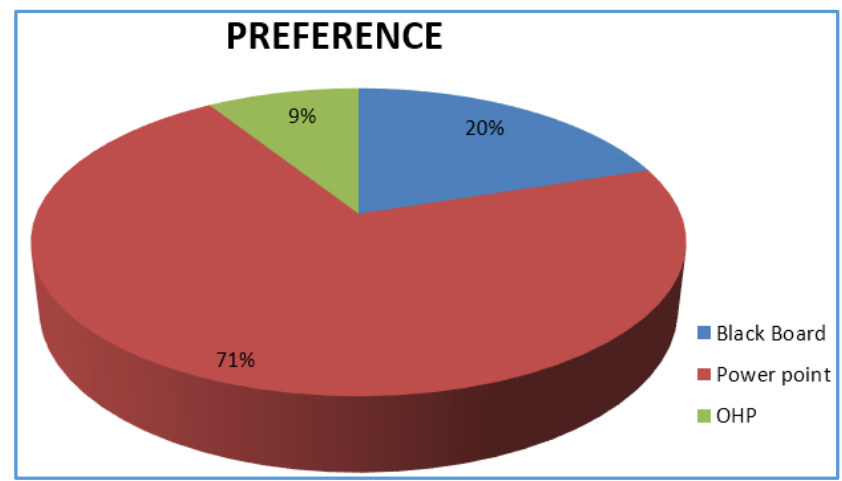

Figure 1. Preference of Different Teaching Aids: MBBS \& Paramedical Students

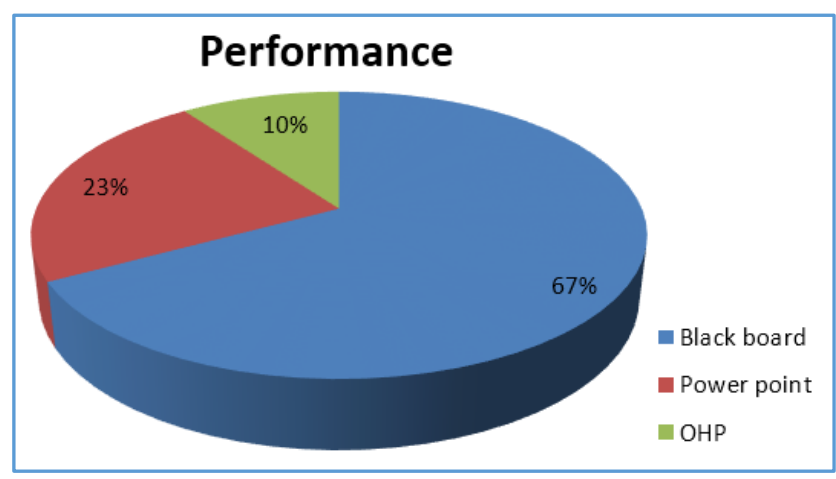

Figure 2. Performance of MBBS \& Paramedical Students with Respect to Teaching Aids

\section{DISCUSSION}

A teaching method is the system of operations and activities of the teacher and his/her students, which help students to acquire knowledge, skills and abilities, develop capabilities, and form a view of the world.
As per our study the student preference by isolated teaching method, it was found that the students preferred PPT over other teaching aids and order of priority was PPT > Blackboard $>$ TOHP.

Regarding performance of students for particular teaching aids, it was found that the order of priority of teaching methods as assessed was Blackboard $>$ PPT $>$ TOHP and this is in accordance with previously conducted studies. $(3,4,5)$

Regarding preference, PPT does seem to have a great impact on student, $(6,7,8,9,10)$ because it can avoid the matter of poor handwriting, dirty blackboard, provides a better quality of text and diagram and it is become more interesting by incorporating animation, picture, graphs, 3D images, sequence of images and videos.(11) In our Government Medical College most of the admissions are from native state with state domicile and only few admissions are through central system of admission. Communication is problem from students of other states, so might these students found multimedia approach better. This could be owing to the fact that the respondents come from a diverse background of different states across India.

Comparing performance PPT was lower than blackboard teaching might be some teachers go too fast and students find it difficult to take down note and diagram,(12) so students become a passive observer rather than an active participant(13) and thus reduces interactive discussion between teacher and students,(14) also the effectiveness of multimedia depends on how it is used in relation to instruction. The inability to move away from the computer desk inhibits a teacher walking freely across the room. Hence, when the faculty tends to focus on the technology the students feel ignored.

Being in teaching for more than one decade, I personally found the traditional blackboard teaching method provides strong student-teacher interaction, more conceptual, operator based and very disciplined, it gives better student-teacher interaction and contains natural pauses (e.g. during writing and rubbing the blackboard) and breaks so that it allows the students to follow the material and take down the note. In this context, a blackboard may be said to be more student-centred while PPT is more teacher-centred.(15)

In this study, students rated blackboard-based teaching more highly for 'facilitating interaction between teachers and students,' 'coping with teaching speed of teacher' and 'arousing interest in learning' and 'holding attention in classes.'

Now as the number of admissions to GGS Medical College has increased from 50 to 100, also MCI reducing the requirement of the Doctors might be the effectiveness of teaching study, what we accessed may swift from Blackboard to Multimedia. As in multimedia curriculum is covered with recorded demonstration with no language problem and also same PPT lecture can be used for teaching different courses. So, younger teachers usually opted for multimedia computerbased lecturing. Blackboard is considered as older teaching modality used by old teachers.

\section{CONCLUSION}

Having analysed we conclude that the dominant form of lecture delivery is still Blackboard, but with younger teachers opting more for multimedia method of teaching and with $\mathrm{MCI}$ granting more seats of MBBS to private colleges and also reducing the faculty strength slowly and gradually the 
blackboard technique of teaching will wane off with the retirement of old experienced teachers. Thus, depriving the students to blackboard teaching will ultimately decrease the quality of medical education. MCI should restrict the number of seats in private colleges and should make definite guidelines to encourage blackboard teaching as the lectures which are made on Multimedia are either downloaded or are shared amongst different faculty members and also same lectures are used. Cross checking of medical certificate is mandatory in the inspection along with that they should also inspect the quality of blackboards, chalks purchased in last six months by that institution, etc.

Much to the contrary, this feedback is expected to act as a guide to aware our fellow senior educationalists and also to the MCI, not to make research articles as whole sole criteria to assess the performance of the teacher. Blackboard teaching has several advantages over the modern teaching aids in a curriculum of classroom teaching. With the passage of time and lack of interest of upcoming teachers blackboard teaching is on the verge of extinction, particularly in Medical profession. So, we expect MCI to take further steps to promote blackboard teaching in Medical Colleges for the welfare of teachers and students. Ultimately, it will raise the standard of teaching in Medical Colleges.

\section{REFERENCES}

1. Foundation for Advancement of International Medical Education and Research (FAIMER $囚$ ) International Medical Education Directory. http://www.imed.ecfmg.org/.

2. Supe A, Burdick WP. Challenges and issues of medical education in India. Acad Med 2006;81(12):1076-80.

3. Parvin R, Haque N, Ahmed N, et al. Is audiovisual method better than traditional for medical students? A survey report. Bangladesh J Medicine 2010;21:60-7.
4. Seth $\mathrm{V}$, Upadhyaya $\mathrm{P}, \mathrm{Ahmad} \mathrm{M}$, et al. Impact of various lecture delivery methods in Pharmacology. EXCLI Journal 2010;9:96-101.

5. Novelli EL, Fernandes AA. Students' preferred teaching techniques for biochemistry in biomedicine and medicine courses. Biochem Mol Biol Educ 2007;35(4):263-6.

6. Sharma R, Verma U, Kapoor B, et al. Novel teaching approaches in Pharmacology. JK Science 2004;6(3):1723.

7. Lowry RB. Electronic presentation of lectures - effect upon student performance. U Chem Ed 1999;8:18-21.

8. Savoy A, Proctor RW, Salvendy G. Information retention from PowerPoint and traditional lectures. Comput \& Educ 2009;52(4):858-67.

9. Rocklin T. PowerPoint is not evil. In: The national teaching and learning forum. New York, NY: Greenwood 1998.

10. Bartsch RA, Cobern KM. Effectiveness of PowerPoint presentations in lectures. Computers and Education 2003;41:77-86.

11. Mayer RE, Anderson RB. The instructive animation: helping students build connections between words and pictures in multimedia learning. J Edu Psych 1992;84(4):444-52.

12. Seth $V$, Upadhyaya $P, A$ Amad $M$, et al. Power point or chalk and talk: perceptions of medical students in a medical college in India. Advances in Medical Education and Practice 2010;1:11-16.

13. Casanova J, Casanova SL. Computers as electronic blackboard: remodeling the organic chemistry lecture. Educom Review 1991;26:31-4.

14. Garg A, Rataboli PV, Muchandi K. Students' opinion on the prevailing teaching methods in pharmacology and changes recommended. Indian J Pharmacol 2004;36(3): 155-8.

15. Creed T. PowerPoint No! Cyberspace Yes! In: The national teaching and learning forum. New York, NY: Greenwood 1998. 